\title{
Synthesis, characterization and photophysical properties of a new 2,5- di(aryl)phosphole derivative and their trigonal copper-phosphole complexes.
}

Neskarlys Rios ${ }^{\mathrm{a}}$, Franmerly Fuentes ${ }^{\mathrm{a}}$, Juan M. Garcia-Garfido, ${ }^{\mathrm{a}}$ *, Yomaira Otero $^{\mathrm{a}, \mathrm{c} *}$

${ }^{a}$ Instituto Venezolano de Investigaciones Científicas (IVIC), Centro de Química, Caracas 1020-A, Venezuela.

bUniversidad de Santiago de Chile, Departamento of Física, Universidad de Santiago de Chile, Av. Ecuador 3493, Estación Central, Santiago, Chile.

'Pontificia Universidad Católica del Ecuador, Facultad de Ciencias Exactas y Naturales, Departamento de Química, Quito, Ecuador.

*Corresponding authors: Juan M. Garcia-Garfido, e-mail: juanmanuelgarfido@ gmail.com, juan.garcia.g@usach.cl; Yomaira Otero,e-mail: yomaira@gmail.com, ye.otero@puce.edu.ec. 


\title{
Synthesis, characterization and photophysical properties of a new 2,5- di(aryl)phosphole derivative and their trigonal copper-phosphole complexes.
}

\begin{abstract}
A new phosphole derivative 2,5-di(2-quinolyl)-1-phenylphosphole (1) was synthesized by using the Fagan-Nugent method. Phosphole $\mathbf{1}$ was obtained as an air stable solid in high yield (73\%). Additionally, two new copper-phosphole complexes [CuX(Phosphole $\left.)_{2}\right](\mathrm{X}=\mathrm{Cl}(\mathbf{2 a}), \mathrm{I}(\mathbf{2 b})$, Phosphole = 1) have been synthesized by reaction of $\mathrm{CuX}(\mathrm{X}=\mathrm{Cl}, \mathrm{I})$ and phosphole derivative (1). All compound were characterized by NMR, ESI-MS, UV-Vis and fluorescence spectroscopy. The photophysical properties of all compounds were analyzed, UV-Vis spectra of the complexes $\mathbf{2 a - b}$ shown $\pi-\pi^{*}$ transitions with shift very similar to the found in the free phosphole due to that their symmetrical structures inhibits efficient ILCT. We have found that the compounds 1, 2a-b exhibited fluorescence between 460 and 583 $\mathrm{nm}$ with quantum yields of $\Phi_{\mathrm{f}}=0.04-0.11$. The emission energy of $\mathbf{2 b}$ is higher than 2a, suggesting that $\lambda_{\max }$ is affected by the ligand-field strength of the halogen ions in the complexes $\left(\mathrm{I}^{-}<\mathrm{Cl}^{-}\right)$.

Keywords: phosphole, copper-phosphole complexes, bis(quinolyl)phosphole, photophysical properties, fluorescent $\mathrm{Cu}$-complexes.
\end{abstract}

\section{Introduction}

Luminescent transition metal complexes have gained much attention due to their potential application in organic light-emitting diodes (OLEDs) and light-emitting electrochemical cells (LECs) [1-7]. Copper(I)-containing complexes have been extensively studied because of their relative abundance and low cost, moreover, they have demonstrated a wave variety of applications in solar energy conversion, luminescence-based sensors, catalysis and probes of biological systems $[4,8-16]$. Nowadays, it is well-know that the use of bulky and rigid 
ligands regulate the structure and configuration of copper (I) complexes, leading to effective suppression of the nonradiative processes, which is the key to synthesize highly efficient $\mathrm{Cu}(\mathrm{I})$-complexes [17-20]. Additionally, different studies have reported that the nature of ligands, specifically halides and phosphines, affect the luminescence properties of $\mathrm{Cu}(\mathrm{I})$ compounds [21-25]. Particularly, three-coordinate $\mathrm{Cu}(\mathrm{I})$ halide coordinated by phosphine ligands have showed high luminescent efficiency [26-30].

On the other hand, phosphole ligands have attracted growing interest for the development of complexes due to their ability to act as $\int$-ligands through the nucleophilic phosphorus atom [31-33], allowing a tuning of their photophysical properties which has been used in the development of multifunctional materials for OLEDs and catalytic reactions [16,34-38].

Based on the interesting electronic properties that present both phospholes-complexes and three-coordinate mononuclear $\mathrm{Cu}(\mathrm{I})$ halide with phosphine ligands, we have synthesized a new rigid phoshole with pi-conjugated system (1) and two trigonal copper-phosphole complexes (2a-b). Their spectroscopy characterization and photophysical properties are described.

\section{Experimental section}

\subsection{Materials and methods}

All experiments were performed under an atmosphere of dry argon in the dark using a standard Schlenk technique. The solvents were previously dried and distilled following standard methods prior to use [39]. Dibromidephenylphosphine $\left(\mathrm{PhPBr}_{2}\right)$ was synthesized according to published procedures [40]. ${ }^{31} \mathrm{P},{ }^{1} \mathrm{H}$ and ${ }^{13} \mathrm{C}$ NMR spectra were recorded using a Bruker Advance AM 300 and AM600 spectrometers. Mass spectra were acquired on a Thermo Scientific TSQ Quantum Ultra AM Triple Quadrupole mass spectrometer employing the Heated Electrospray Ionization (HESI) technique. The UV-Vis spectra were recorded on a PerkinElmer Lambda 2 spectrophotometer. All fluorescence spectra were recorded at room temperature at $10^{-6} \mathrm{M}$ on a PerkinElmer L545 fluorescence spectrometer with a pulse xenon lamp, the fluorescence quantum yield was determined in $\mathrm{CH}_{2} \mathrm{Cl}_{2}$ on freshly prepared samples (air-equilibrated). Samples of tetraphenylporphyrin in $\mathrm{CH}_{2} \mathrm{Cl}_{2}$ were employed as a standard $\left(\Phi_{\mathrm{f}}=0.11\right)$. 


\subsection{Synthesis of 1-phenyl-2,5-di(2-quinolyl)phosphole (1)}

A solution of $\mathrm{n}-\mathrm{BuLi}$ in hexane $(1.6 \mathrm{M}, 1.9 \mathrm{~mL} ; 3.05 \mathrm{mmol})$ was added dropwise to a solution of 1,8-di(2-quinolyl)octa-1,7-diyne (500.0 mg; $1.39 \mathrm{mmol}$ ) and [Cp $\left.\mathrm{ZrCl}_{2}\right]$ (405.6 mg; 1.39 mmol) in THF $(25 \mathrm{~mL})$ at $-78{ }^{\circ} \mathrm{C}$. The reaction mixture was warmed to room temperature and stirred for $12 \mathrm{~h}$. Freshly distilled $\mathrm{PhPBr}_{2}(383.6 \mathrm{mg} ; 1.43 \mathrm{mmol}$ ) was added to this solution at $-78{ }^{\circ} \mathrm{C}$. The solution was allowed to warm to room temperature and stirred for 24 $\mathrm{h}$. The solution was filtered, and the volatile materials were removed under vacuum. After purification on basic alumina ( 4 × $25 \mathrm{~mL}$ THF) and the washing on pentane, 1 was obtained

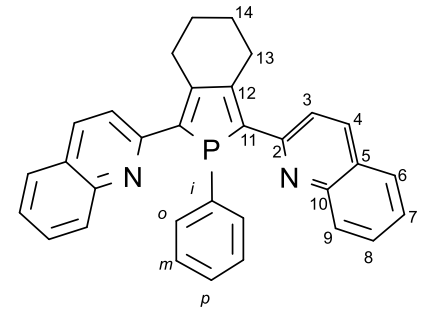
as a yellow solid (yield: $472.9 \mathrm{mg} ; 73 \%) . \quad \mathbf{N M R}-{ }^{31} \mathbf{P}\left\{{ }^{1} \mathbf{H}\right\}(\mathbf{2 0 0}$ $\left.\mathbf{M H z}, \mathbf{C D C l}_{3}\right): \delta=12.36$ (s). NMR- ${ }^{1} \mathbf{H}\left(\mathbf{6 0 0} \mathbf{M H z},\left(\mathrm{CD}_{3}\right)_{2} \mathbf{C O}\right): \delta$

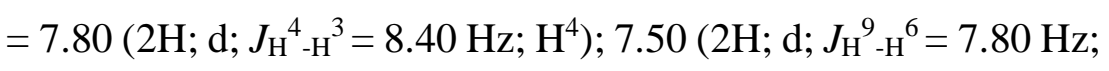

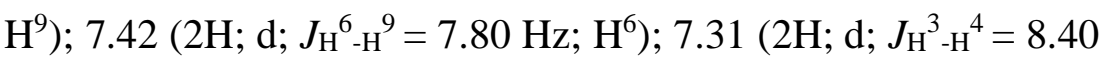
$\left.\mathrm{Hz} ; \mathrm{H}^{3}\right) ; 7.26\left(2 \mathrm{H} ; \mathrm{t} ; \mathrm{J}^{8}{ }_{-}^{8}{ }^{7}=7.20 \mathrm{~Hz} ; \mathrm{H}^{8}\right) ; 7.06\left(2 \mathrm{H} ; \mathrm{t} ; J_{\mathrm{H}^{7}-\mathrm{H}^{8}}=\right.$ $\left.7.20 \mathrm{~Hz} ; \mathrm{H}^{7}\right) ; 6.93\left(2 \mathrm{H} ; \mathrm{m} ; \mathrm{H}^{o}\right) ; 6.63\left(3 \mathrm{H} ; \mathrm{m} ; \mathrm{H}^{p}\right.$ and $\left.\mathrm{H}^{m}\right) 3.12\left(2 \mathrm{H} ; \mathrm{m} ; \mathrm{H}^{13 \mathrm{a}}\right) ; 2.47(2 \mathrm{H} ; \mathrm{m} ;$ $\left.\mathrm{H}^{13 b}\right) ; 1.45\left(2 \mathrm{H} ; \mathrm{m} ; \mathrm{H}^{14 \mathrm{a}}\right) ; 1.28\left(2 \mathrm{H} ; \mathrm{m} ; \mathrm{H}^{14 b}\right)$. NMR- ${ }^{13} \mathbf{C}\left\{{ }^{1} \mathbf{H}\right\}\left(\mathbf{2 0 0} \mathbf{~ M H z},\left(\mathbf{C D}_{3}\right)_{2} \mathbf{C O}\right): \delta=$ $145.42\left(\mathrm{~d} ;{ }^{2} J_{\mathrm{PC}}=18.00 \mathrm{~Hz} ; \mathrm{C}^{2}\right) ; 139.25\left(\mathrm{~d} ;{ }^{2} J_{\mathrm{PC}}=10.60 \mathrm{~Hz} ; \mathrm{C}^{12}\right) ; 137.85\left(\mathrm{~s} ; \mathrm{C}^{5}\right) ; 135.48(\mathrm{~s} ;$ $\left.\mathrm{C}^{11}\right) ; 126.40\left(\mathrm{~s} ; \mathrm{C}^{4}\right) ; 124.77\left(\mathrm{~s} ; \mathrm{C}^{i}\right) ; 123.86\left(\mathrm{~d} ;{ }^{2} J_{\mathrm{PC}}=17.70 \mathrm{~Hz} ; \mathrm{C}^{o}\right) ; 120,08\left(\mathrm{~s} ; \mathrm{C}^{8}\right) ; 118.89$ $\left(\mathrm{s} ; \mathrm{C}^{9}\right) ; 118.76\left(\mathrm{~s} ; \mathrm{C}^{p}\right) ; 118.70\left(\mathrm{~s} ; \mathrm{C}^{m}\right) ; 117.97\left(\mathrm{~s} ; \mathrm{C}^{6}\right) ; 116.36\left(\mathrm{~s} ; \mathrm{C}^{7}\right) ; 116.21\left(\mathrm{~s} ; \mathrm{C}^{10}\right) ; 112.17$ $\left(\mathrm{d} ;{ }^{3} J_{\mathrm{PC}}=8.90 \mathrm{~Hz} ; \mathrm{C}^{3}\right) ; 18.94\left(\mathrm{~s} ; \mathrm{C}^{13}\right) ; 12.81\left(\mathrm{~s} ; \mathrm{C}^{14}\right) . \mathrm{MS}\left(\mathrm{CH}_{2} \mathrm{Cl}_{2}, \mathrm{ESI}\right): \mathrm{m} / \mathrm{z}: 469.19$ $\left[\mathrm{C}_{32} \mathrm{H}_{25} \mathrm{~N}_{2} \mathrm{PH}\right]^{+}$. UV-Vis $\left(\mathrm{CH}_{2} \mathrm{Cl}_{2}\right), \lambda_{\max }(\mathrm{nm}): 240 \mathrm{~nm}\left(\varepsilon=775023 \mathrm{M}^{-1} \mathrm{~cm}^{-1}\right), 402(\varepsilon=$ $\left.279991 \mathrm{M}^{-1} \mathrm{~cm}^{-1}\right)$. Fluorescence $\left(\mathrm{CH}_{2} \mathrm{Cl}_{2}\right), \lambda_{\max }(\mathrm{nm}): 460 \mathrm{~nm}, \Phi_{\mathrm{f}}=0.04$.

\subsection{Synthesis of [CuCl(1-phenyl-2,5-di(2-quinolyl)phosphole $\left.)_{2}\right](2 a)$}

A solution of $1(157.7 \mathrm{mg}$; $0.34 \mathrm{mmol})$ and $\mathrm{CuCl}(16.9 \mathrm{mg} ; 0.17 \mathrm{mmol})$ in $\mathrm{CH}_{2} \mathrm{Cl}_{2}(15 \mathrm{~mL})$ was stirred at room temperature under argon for $24 \mathrm{~h}$. The solvent was removed under vacuum and the remaining solid washed on pentane $(4 \times 10 \mathrm{~mL})$ to give $2 \mathbf{a}$ as a red solid (yield: $151.3 \mathrm{mg} ; 87 \%)$. NMR- ${ }^{31} \mathbf{P}\left\{{ }^{1} \mathbf{H}\right\}\left(\mathbf{2 0 0} \mathbf{M H z}, \mathbf{C D C l}_{3}\right): \delta=4.57$ (s) $\mathbf{N M R}-{ }^{1} \mathbf{H}(\mathbf{6 0 0}$ MHz, $\left.\mathbf{C D C l}_{3}\right): \delta=8.23\left(4 \mathrm{H} ; \mathrm{m} ; \mathrm{H}^{4}\right) ; 7.86\left(4 \mathrm{H} ; \mathrm{d} ; \mathrm{H}^{9}\right) ; 7.53\left(8 \mathrm{H} ; \mathrm{m} ; \mathrm{H}^{6}\right.$ y H $\left.\mathrm{H}^{3}\right) ; 7.46(8 \mathrm{H} ; \mathrm{m}$; $\mathrm{H}^{8}$ and $\left.\mathrm{H}^{7}\right) ; 7.36\left(4 \mathrm{H} ; \mathrm{m} ; \mathrm{H}^{o}\right) ; 7.11\left(6 \mathrm{H} ; \mathrm{m} ; \mathrm{H}^{p}\right.$ and $\left.\mathrm{H}^{m}\right) ; 3.34\left(4 \mathrm{H} ; \mathrm{m} ; \mathrm{H}^{13 \mathrm{a}}\right) ; 2.72(4 \mathrm{H} ; \mathrm{m}$; $\left.\mathrm{H}^{13 \mathrm{~b}}\right) ; 1.74\left(4 \mathrm{H} ; \mathrm{m} ; \mathrm{H}^{14 \mathrm{a}}\right) ; 1.69\left(4 \mathrm{H} ; \mathrm{m} ; \mathrm{H}^{14 b}\right)$. NMR- ${ }^{13} \mathbf{C}\left\{{ }^{1} \mathbf{H}\right\}\left(\mathbf{2 0 0} \mathbf{M H z}, \mathbf{C D C l}_{3}\right): \delta=154.13$ $\left(\mathrm{s} ; \mathrm{C}^{2}\right) ; 152.37\left(\mathrm{~s} ; \mathrm{C}^{12}\right) ; 147.77\left(\mathrm{~s} ; \mathrm{C}^{5}\right) ; 135.72\left(\mathrm{~d} ; \mathrm{C}^{11}\right) ; 133.70\left(\mathrm{~s} ; \mathrm{C}^{4}\right) ; 130.15\left(\mathrm{~s} ; \mathrm{C}^{i}\right) ; 129.75$ 
$\left(\mathrm{s} ; \mathrm{C}^{o}\right) ; 129.50\left(\mathrm{~s} ; \mathrm{C}^{8}\right) ; 129.34\left(\mathrm{~s} ; \mathrm{C}^{9}\right) ; 127.42\left(\mathrm{~s} ; \mathrm{C}^{p}\right) ; 127.21\left(\mathrm{~s} ; \mathrm{C}^{m}\right) ; 126.26\left(\mathrm{~s} ; \mathrm{C}^{6}\right) ; 126.05$ $\left(\mathrm{s} ; \mathrm{C}^{7}\right) ; 124.24\left(\mathrm{~s} ; \mathrm{C}^{10}\right) ; 122.36\left(\mathrm{~s} ; \mathrm{C}^{3}\right) ; 29.74\left(\mathrm{~s} ; \mathrm{C}^{13}\right) ; 22.63\left(\mathrm{~s} ; \mathrm{C}^{14}\right) . \mathrm{MS}\left(\mathrm{CH}_{2} \mathrm{Cl}_{2}, \mathrm{ESI}\right): \mathrm{m} / \mathrm{z}$ : $999.31\left[\mathrm{C}_{64} \mathrm{H}_{50} \mathrm{~N}_{4} \mathrm{P}_{2} \mathrm{Cu}\right]^{+}$. UV-Vis $\left(\mathrm{CH}_{2} \mathrm{Cl}_{2}\right), \lambda_{\max }(\mathrm{nm}): 240 \mathrm{~nm}\left(\varepsilon=909294 \mathrm{M}^{-1} \mathrm{~cm}^{-1}\right), 403$ $\left(\varepsilon=322051 \mathrm{M}^{-1} \mathrm{~cm}^{-1}\right)$. Fluorescence $\left(\mathrm{CH}_{2} \mathrm{Cl}_{2}\right), \lambda_{\max }(\mathrm{nm}): 583 \mathrm{~nm}, \Phi_{\mathrm{f}}=0.07$.

\subsection{Synthesis of [CuI(1-phenyl-2,5-di(2-quinolyl)phosphole) $)_{2}$ (2b)}

A solution of $1(170.8 \mathrm{mg} ; 0.36 \mathrm{mmol})$ and $\mathrm{CuI}(33.9 \mathrm{mg} ; 0.18 \mathrm{mmol})$ in $\mathrm{CH}_{2} \mathrm{Cl}_{2}(15 \mathrm{~mL})$ was stirred at room temperature under argon for $24 \mathrm{~h}$. The solvent was removed under vacuum and the remaining solid washed on pentane $(4 \times 10 \mathrm{~mL})$ to give $\mathbf{2 b}$ as an orange solid (yield: $187.8 \mathrm{mg}$; 88\%). NMR- ${ }^{31} \mathbf{P}\left\{{ }^{\mathbf{1}} \mathbf{H}\right\}\left(\mathbf{1 2 1}, \mathbf{4} \mathbf{~ M H z}, \mathbf{C D}_{2} \mathbf{C l}_{2}\right): \delta=2.22$. NMR- ${ }^{1} \mathbf{H}(\mathbf{6 0 0}$ MHz, CDCl $): \delta=8,20\left(4 \mathrm{H} ; \mathrm{m} ; \mathrm{H}^{4}\right) ; 7.87\left(4 \mathrm{H} ; \mathrm{d} ; \mathrm{H}^{9}\right) ; 7.51\left(8 \mathrm{H} ; \mathrm{m} ; \mathrm{H}^{6}\right.$ and $\left.\mathrm{H}^{3}\right) ; 7.45(4 \mathrm{H}$; $\left.\mathrm{m} ; \mathrm{H}^{8}\right) 7.41\left(4 \mathrm{H} ; \mathrm{m} ; \mathrm{H}^{7}\right) ; 7.31\left(4 \mathrm{H} ; \mathrm{m} ; \mathrm{H}^{o}\right) ; 7.09\left(6 \mathrm{H} ; \mathrm{m} ; \mathrm{H}^{p}\right.$ and $\left.\mathrm{H}^{m}\right) ; 3.34\left(4 \mathrm{H} ; \mathrm{m} ; \mathrm{H}^{13 \mathrm{a}}\right)$; $2.82\left(4 \mathrm{H} ; \mathrm{m} ; \mathrm{H}^{13 \mathrm{~b}}\right) ; 1.75\left(8 \mathrm{H} ; \mathrm{m} ; \mathrm{H}^{14 \mathrm{a}, \mathrm{b}}\right) . \mathbf{N M R}-{ }^{13} \mathbf{C}\left\{{ }^{1} \mathbf{H}\right\}\left(\mathbf{1 5 0 , 8} \mathbf{M H z}, \mathbf{C D C l}_{3}\right): \delta=154.64$ $\left(\mathrm{s} ; \mathrm{C}^{2}\right) ; 154.09\left(\mathrm{~s} ; \mathrm{C}^{12}\right) ; 152.12\left(\mathrm{~s} ; \mathrm{C}^{5}\right) ; 148.09\left(\mathrm{~s} ; \mathrm{C}^{11}\right) ; 147.67\left(\mathrm{~s} ; \mathrm{C}^{4}\right) ; 136.01\left(\mathrm{~s} ; \mathrm{C}^{i}\right) ; 135.62$ (s; $\left.\mathrm{C}^{o}\right) ; 133.70\left(\mathrm{~s} ; \mathrm{C}^{8}\right) ; 129.98$ (s; $\left.\mathrm{C}^{9}\right) ; 129.50\left(\mathrm{~s} ; \mathrm{C}^{p}\right) ; 129.25\left(\mathrm{~s} ; \mathrm{C}^{m}\right) ; 128.52\left(\mathrm{~s} ; \mathrm{C}^{6}\right) ; 127.16$ $\left(\mathrm{s} ; \mathrm{C}^{7}\right) ; 126.23\left(\mathrm{~s} ; \mathrm{C}^{10}\right) ; 125.93\left(\mathrm{~d} ; \mathrm{C}^{3}\right) ; 29.65\left(\mathrm{~s} ; \mathrm{C}^{13}\right) ; 22.70\left(\mathrm{~s} ; \mathrm{C}^{14}\right) . \mathrm{MS}\left(\mathrm{CH}_{2} \mathrm{Cl}_{2}, \mathrm{ESI}\right): \mathrm{m} / \mathrm{z}$ : $999.31\left[\mathrm{C}_{64} \mathrm{H}_{50} \mathrm{~N}_{4} \mathrm{P}_{2} \mathrm{Cu}\right]^{+}$. UV-Vis $\left(\mathrm{CH}_{2} \mathrm{Cl}_{2}\right), \lambda_{\max }(\mathrm{nm}): 239 \mathrm{~nm}\left(\varepsilon=572282 \mathrm{M}^{-1} \mathrm{~cm}^{-1}\right), 403$ $\left(\varepsilon=196877 \mathrm{M}^{-1} \mathrm{~cm}^{-1}\right)$. Fluorescence $\left(\mathrm{CH}_{2} \mathrm{Cl}_{2}\right), \lambda_{\max }(\mathrm{nm}): 490 \mathrm{~nm}, \Phi_{\mathrm{f}}=0.11$.

\section{Results and discussion}

\subsection{Synthesis and characterization of 1-phenyl-2,5-di(2-quinolyl)phosphole (1)}

The new phosphole derivative (1) was obtained employing the Fagan-Nugent method [41,42], which involve the oxidative coupling of 1,8-di(2-quinolyl)octa-1,7-diyne [43] with $\left[\mathrm{Cl}_{2} \mathrm{ZrCp}_{2}\right]$ followed by treatment with dibromidephenylphosphine $\left(\mathrm{PhPBr}_{2}\right)$ (Scheme 1). The phosphole derivative is purified by flash column chromatography $\left(\mathrm{Al}_{2} \mathrm{O}_{3}\right.$ basic, eluant: THF) and isolated as air-stable yellow solid in high yield (73\%). The new phosphole (1) was stable in different solvents such as THF, $\mathrm{CH}_{2} \mathrm{Cl}_{2}, \mathrm{CHCl}_{3}$, DMSO and acetone. The ESI-MS spectrum of compound 1 displayed a peak at $\mathrm{m} / \mathrm{z} 469.19$, which matches with the molecular ion $\left.[\mathbf{1}+\mathrm{H}]^{+}=\left[\mathrm{C}_{32} \mathrm{H}_{25} \mathrm{~N}_{2} \mathrm{PH}\right]^{+}\right]$. Its ${ }^{31} \mathrm{P}\left\{{ }^{1} \mathrm{H}\right\}$ NMR spectrum showed only a singlet at ${ }^{\mathrm{TM}}+12.36$ ppm, whose shift is similar to that found for related symmetrical 2,5-disubstituted 1phenylphospholes [31]. On the other hand, all ${ }^{1} \mathrm{H}$ and ${ }^{13} \mathrm{C}\left\{{ }^{1} \mathrm{H}\right\}$ NMR signals were 
unequivocally assigned on the basis of 1D and 2D, correlation spectroscopy (COSY), heteronuclear multiple quantum correlation (HMQC) and heteronuclear multiple bond correlation (HMBC) experiments (for complete NMR data see experimental section). Thus, their ${ }^{1} \mathrm{H}$ and ${ }^{13} \mathrm{C}\left\{{ }^{1} \mathrm{H}\right\}$ NMR spectra showed signals consistent with the structure of the phosphole 1.
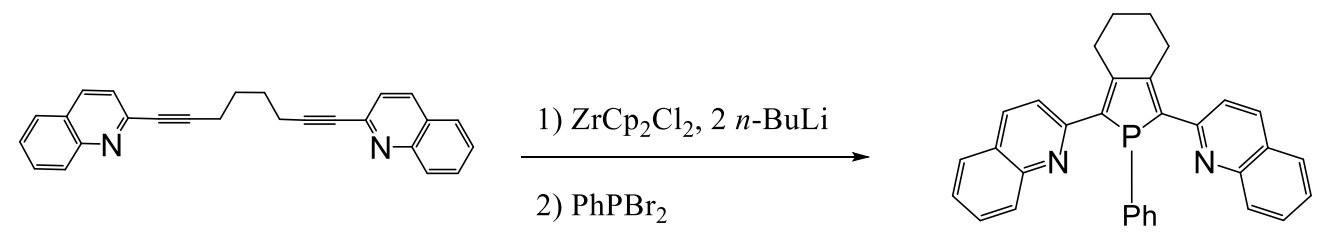

(1)
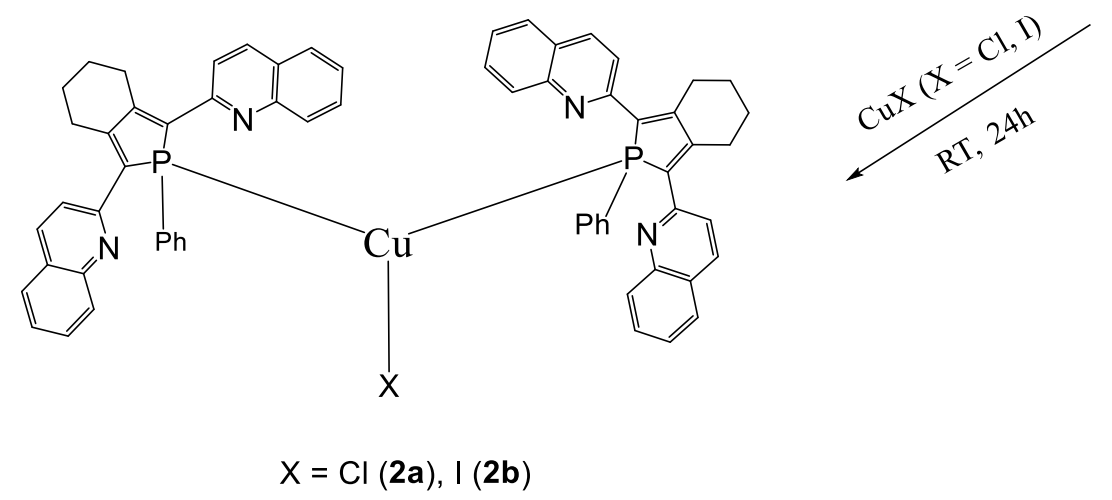

Scheme 1. Synthesis of phosphole $\mathbf{1}$ and their complexes $\mathbf{2 a - b}$.

\subsection{Synthesis and characterization of [CuX(1-phenyl-2,5-di(2-quinolyl)phosphole $\left.)_{2}\right](X=$} $C l(2 a), I(2 b))$

The reaction of $\mathrm{CuX}(\mathrm{X}=\mathrm{Cl}, \mathrm{Br}, \mathrm{I})$ with two equivalent of phosphole $\mathbf{1}$ in dichloromethane as solvent at RT for $24 \mathrm{~h}$ lead to the complexes [CuX(Phosphole) $\left.)_{2}\right](\mathrm{X}=\mathrm{Cl}(\mathbf{2 a}), \mathrm{I}(\mathbf{2 b})$, Phosphole = 1), the complex with bromide not was observed. 2a-b were isolated in good yields as air stables red and orange solids, respectively (87\% 2a, 88\% 2b yields). Both complexes 2a-b were stable in different solution such as $\mathrm{CH}_{2} \mathrm{Cl}_{2}, \mathrm{CHCl}_{3}, \mathrm{DMSO}$; slightly soluble in $\mathrm{Et}_{2} \mathrm{O}$, THF; and insoluble in pentane and $\mathrm{H}_{2} \mathrm{O}$.

The ESI-MS spectra of the complexes 2a-b depict a peak of high intensity corresponding to the molecular ion $\left[\mathrm{C}_{64} \mathrm{H}_{50} \mathrm{~N}_{4} \mathrm{P}_{2} \mathrm{Cu}\right]^{+}$at $\mathrm{m} / \mathrm{z} 999.31$ in both cases. These are consistent with a copper atom and two phosphole ligands, suggesting that the compounds obtained are of the type [M-X-Phosphole]. The ${ }^{31} \mathrm{P},{ }^{1} \mathrm{H}$ and ${ }^{13} \mathrm{C}$ signals showed variations in 
their chemical shifts with respect to those of the free phosphole, being the $\Delta^{\mathrm{TM}}$ used as a parameter to deduce the binding mode of 1 to the metal center. The ${ }^{31} \mathrm{P}\left\{{ }^{1} \mathrm{H}\right\} \mathrm{NMR}$ spectra of both complexes exhibit only a singlet signal high-field shifted in comparison to the free phosphole $\left({ }^{\mathrm{TM}}=4.57(\mathbf{2 a})\right.$ and $\left.2.22(\mathbf{2 b}) \mathrm{ppm}\right)$, indicating that each compound correspond to a disubstituted $\mathrm{Cu}$-complex with two equivalent phosphorus atoms. Their ${ }^{1} \mathrm{H}$ and ${ }^{13} \mathrm{C}\left\{{ }^{1} \mathrm{H}\right\}$ NMR spectra showed very small differences compared to those of the free ligand, suggesting that each complex present a $\int$-coordination of the two phosphole ligands and a symmetrical structure. Based on the available data, the structures shown for $\mathbf{2 a - b}$ in Scheme 1 are the most likely. Thus, the compounds $\mathbf{2 a - b}$ correspond to 16-electron symmetric $\mathrm{Cu}(\mathrm{I})$-complexes in the usual $\mathrm{d}^{10}$ trigonal planar coordination geometry as we have been previously reported for $\left[\mathrm{Cu}\{1 \text {-phenyl-2,5-bis(2-thienyl)phosphole }\}_{2} \mathrm{Cl}\right][44]$.

\subsection{Photophysical properties}

Phosphole ligand and their complexes were analyzed by UV-Vis and fluorescence spectroscopy to evaluate and compare their electronic properties. The spectroscopic data are summarized in Table $X$. The measured absorption and emission spectra of all compounds were recorded in $\mathrm{CH}_{2} \mathrm{Cl}_{2}$ at room temperature. These spectra were measured at an identical molar concentration $\left(1 \times 10^{-6} \mathrm{M}\right)$, so that a direct comparison of absorbance could be made.

The phosphole ligand (1) exhibit an absorption at $402 \mathrm{~nm}$ in the visible region of its UV-vis spectrum, that is attributed to the $\pi-\pi^{*}$ transitions of the extended p-conjugated system of the phosphole ligand $[31,45,46]$. UV-Vis spectra of both complexes 2a-b (Figure 1) showed $\pi-\pi^{*}$ transitions with shift very similar to the observed in the free phosphole, which can be due to the symmetrical structure of the complexes, that inhibits efficient ILCT [31]. 


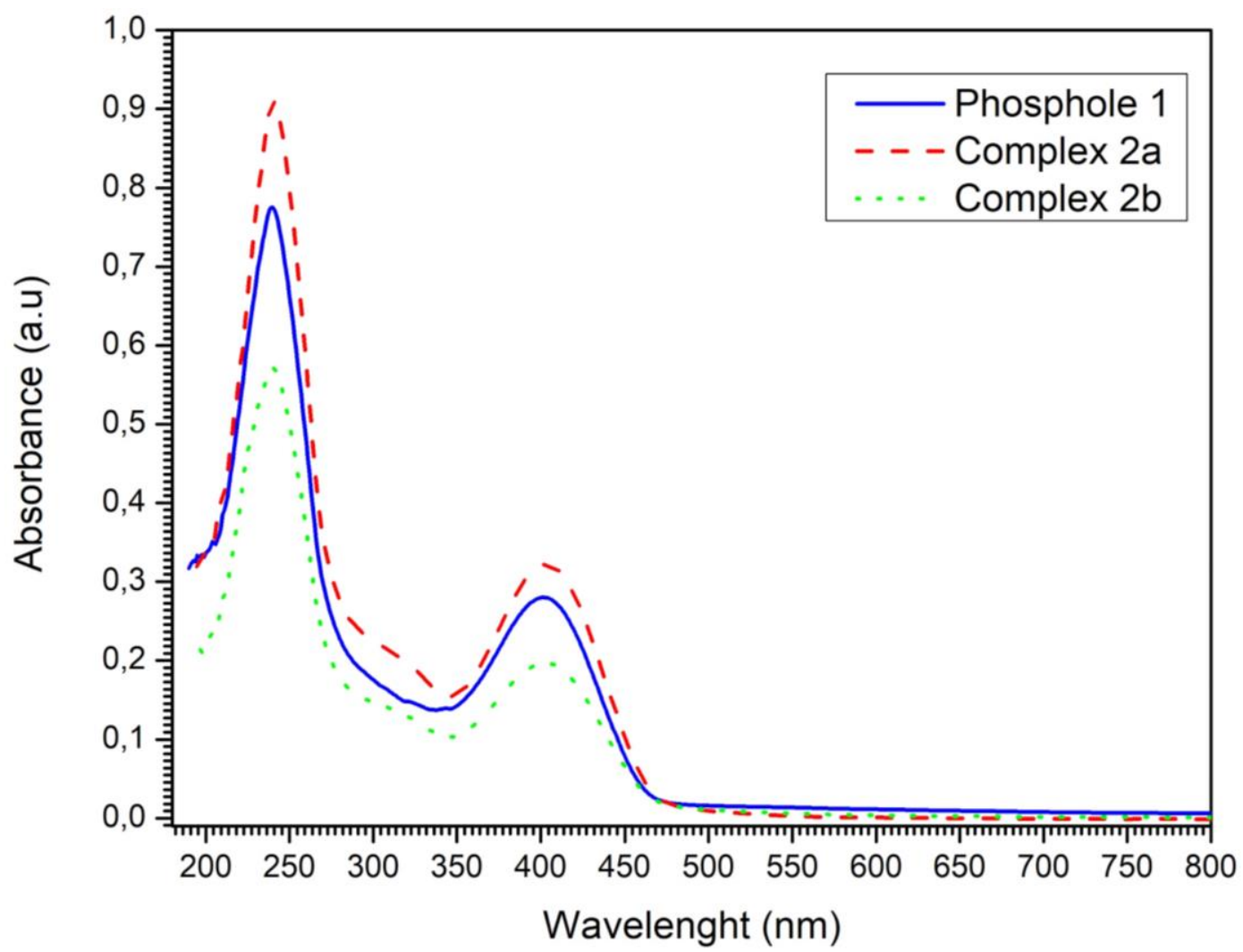

Figure 1. UV-Vis absorption spectra for the phosphole $\mathbf{1}$ and their complexes 2a-b in $\mathrm{CH}_{2} \mathrm{Cl}_{2}$ at room temperature and $[\mathrm{c}]=10^{-6} \mathrm{M}$.

The measured UV-excited $(\lambda=240 \mathrm{~nm})$ fluorescence spectra have shown that phosphole ligand and their corresponding complexes exhibit emission between 460 and 583 $\mathrm{nm}$ (Figure 2). A wide range of Stokes shifts were found for all compound (Table 1), in which complex 2a displays the largest $\Delta \lambda$ value $(180 \mathrm{~nm})$ and the phosphole $\mathbf{1}$ displays the shortest one $(\Delta \lambda=58 \mathrm{~nm})$. The emission bands of the complexes are broad and unstructured, suggesting that the emissive excited states have charge-transfer character [26,47]. The emission energy of $\mathbf{2 b}$ is higher than $\mathbf{2 a}$, suggesting that $\lambda_{\max }$ is affected by the ligand-field strength of the halogen ions in the complexes $\left(\mathrm{I}^{-}<\mathrm{Cl}^{-}\right)$. Presumably the electronic nature of the triplet excited state of $\mathbf{2} \mathbf{a}-\mathbf{b}$ is influenced to some extent by $\mathrm{X}^{-} \rightarrow \pi^{*}(\mathbf{1})$ charge-transfer transitions [25-27,47-49]. 


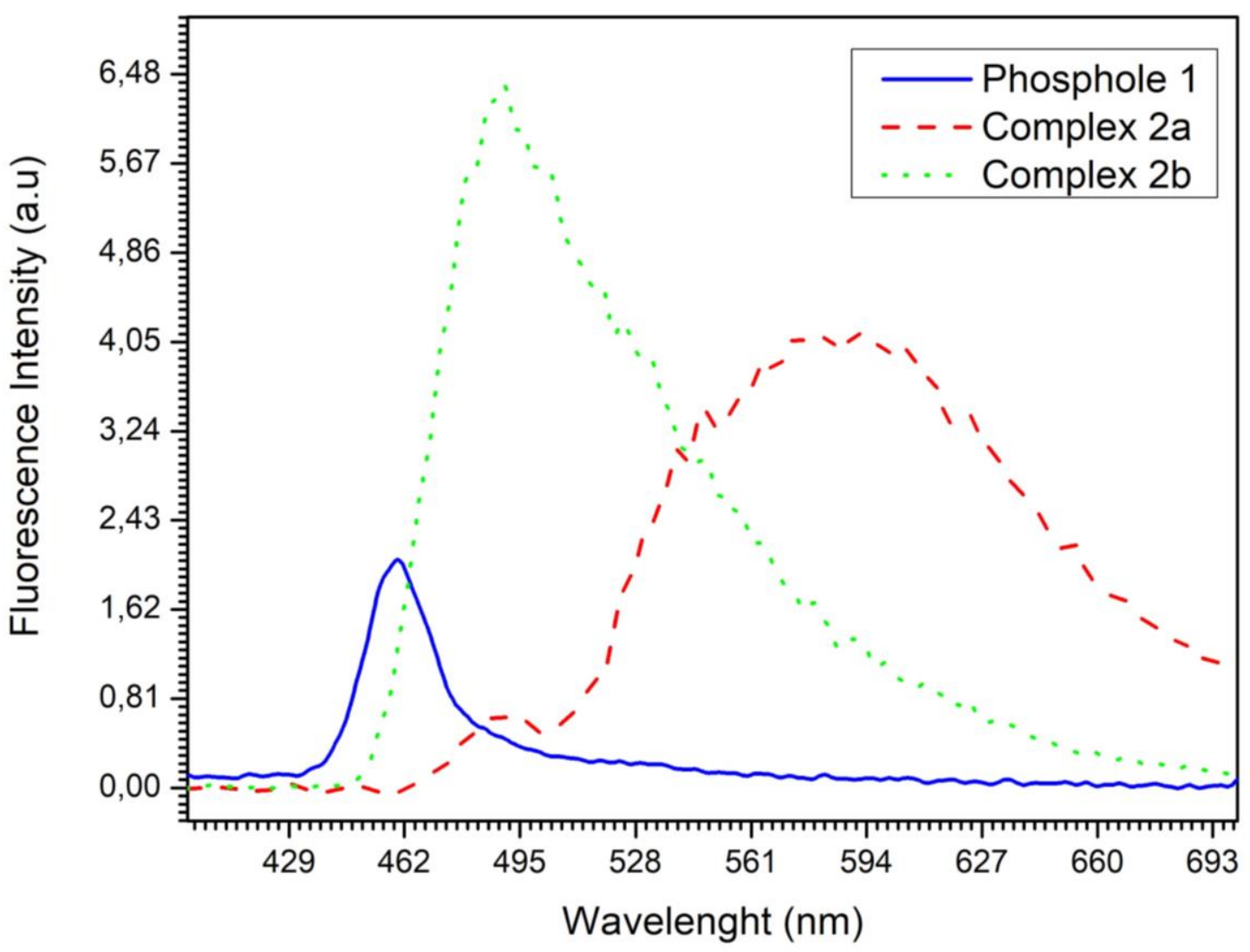

Figure 2. Fluorescence emission spectra $(\lambda=240 \mathrm{~nm})$ for the phosphole $\mathbf{1}$ and their complexes $\mathbf{2 a - b}$ in $\mathrm{CH}_{2} \mathrm{Cl}_{2}$ at room temperature and $[\mathrm{c}]=10^{-6} \mathrm{M}$.

Phosphole 1 showed a quantum yield low $\left(\Phi_{\mathrm{f}}=0.04\right)$ due to chromophores that present $\int^{3}$-P centers generally exhibit almost no fluorescence as a result of quenching by the lone pair of the phosphorus atom [32,36,50-53]. Coordination of the phosphole ligands to metal center has an impact in the quantum yields [31,32,54], showing in the complexes 2ab values higher than those of the corresponding free phosphole $\left(\Phi_{\mathrm{f}}=0.07(\mathbf{2 a}) ; 0.11(\mathbf{2 b})\right)$. It is also noteworthy that the complex $\mathbf{2} \mathbf{b}$ exhibiting the highest value in solution. The values of fluorescence quantum yield of these complexes are highest that the found in trigonal $\mathrm{Cu}(\mathrm{I})$ phosphine halide complexes [26,29]. 
Table 1. UV-Vis and fluorescence spectra of phosphole (1) and their complexes (2a-b).

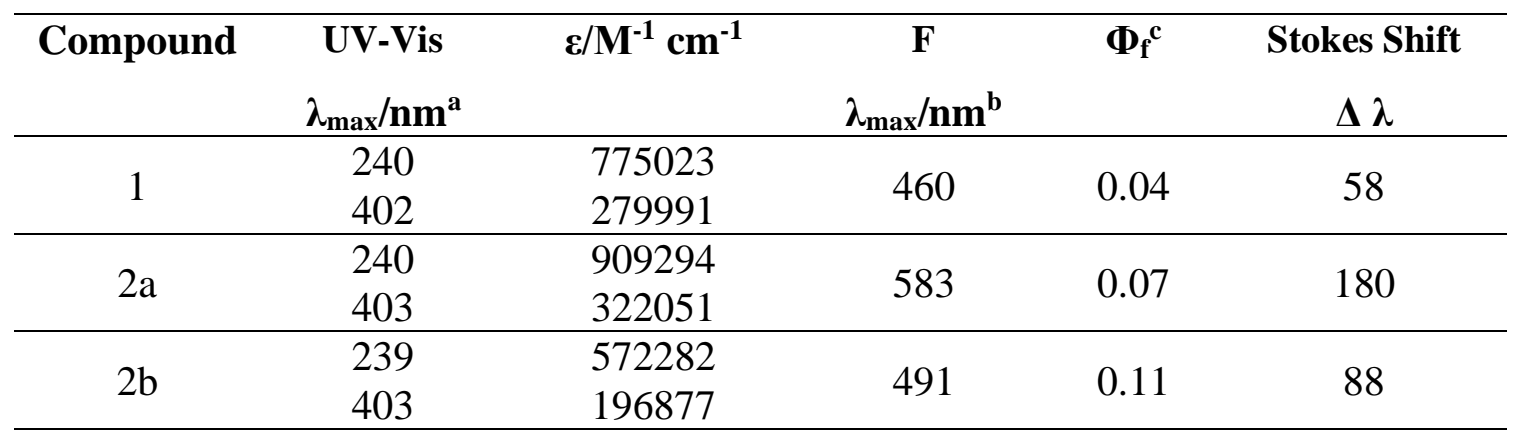

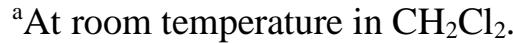

${ }^{\mathrm{b}}$ At room temperature in $\mathrm{CH}_{2} \mathrm{Cl}_{2} \cdot[\mathbf{1}, \mathbf{2 a}-\mathbf{b}]=10^{-6} \mathrm{M}$

${ }^{c}$ Fluorescence quantum yield in $\mathrm{CH}_{2} \mathrm{Cl}_{2}$ relative to tetraphenylporphyrin $\left(\Phi_{\mathrm{f}}=0.11\right)$.

\section{Conclusions}

We have synthesized a new 2,5-di(aryl)phosphole derivative (1) by the Fagan-Nugent method in high yield. Additionally, we have obtained two new three-coordinate mononuclear $\mathrm{Cu}(\mathrm{I})$ halide complexes (2a-b) through the reaction of $\mathrm{CuX}(\mathrm{X}=\mathrm{Cl}$, I) with two equivalent of 1. All the compounds were characterized by analytical and spectroscopic techniques. The photophysical studies showed that all complexes exhibit fluorescence with quantum yields $\Phi_{\mathrm{f}}=0.04-0.11$, being the highest value for complex $\mathbf{2} \mathbf{b}$. These new complexes open up the possibility of new researches in catalytic applications or studies of their biological activities as we have previously reported $[16,44]$.

\section{Acknowledgements}

We thank the Instituto Venezolano de Investigaciones Científicas for financial support (Project $\mathrm{N}^{\circ} 1082$ and 1210). The authors thank Dr. Tamara Zoltan and William Castro for allowing us to use the UV-Vis and fluorescence spectrometers of their laboratories at the IVIC.

\section{Supplementary data}

NMR and MS spectra of all compounds are found in supplementary material.

\section{References}

[1] A.P. De Silva, D.B. Fox, A.J.M. Huxley, T.S. Moody, Combining luminescence, coordination and electron transfer for signalling purposes, Coord. Chem. Rev. 205 (2000) 41-57. 
[2] A. Vogler, H. Kunkely, Luminescent metal complexes: diversity of excited states, in: Transit. Met. Rare Earth Compd., Springer, 2001: pp. 143-182.

[3] M.A. Baldo, D.F. O'Brien, Y. You, A. Shoustikov, S. Sibley, M.E. Thompson, S.R. Forrest, Highly efficient phosphorescent emission from organic electroluminescent devices, Nature. 395 (1998) 151-154.

[4] H. Yersin, A.F. Rausch, R. Czerwieniec, T. Hofbeck, T. Fischer, The triplet state of organo-transition metal compounds. Triplet harvesting and singlet harvesting for efficient OLEDs, Coord. Chem. Rev. 255 (2011) 2622-2652.

[5] P.-T. Chou, Y. Chi, M.-W. Chung, C.-C. Lin, Harvesting luminescence via harnessing the photophysical properties of transition metal complexes, Coord. Chem. Rev. 255 (2011) 2653-2665.

[6] S. Lamansky, P. Djurovich, D. Murphy, F. Abdel-Razzaq, H.-E. Lee, C. Adachi, P.E. Burrows, S.R. Forrest, M.E. Thompson, Highly phosphorescent biscyclometalated iridium complexes: synthesis, photophysical characterization, and use in organic light emitting diodes, J. Am. Chem. Soc. 123 (2001) 4304-4312.

[7] E. Holder, B.M.W. Langeveld, U.S. Schubert, New trends in the use of transition metal-ligand complexes for applications in electroluminescent devices, Adv. Mater. 17 (2005) 1109-1121.

[8] C.A. Bignozzi, R. Argazzi, C.J. Kleverlaan, Molecular and supramolecular sensitization of nanocrystalline wide band-gap semiconductors with mononuclear and polynuclear metal complexes, Chem. Soc. Rev. 29 (2000) 87-96.

[9] V. Balzani, S. Campagna, G. Denti, A. Juris, S. Serroni, M. Venturi, Designing dendrimers based on transition-metal complexes. Light-harvesting properties and predetermined redox patterns, Acc. Chem. Res. 31 (1998) 26-34.

[10] D.R. McMillin, K.M. McNett, Photoprocesses of copper complexes that bind to DNA, Chem. Rev. 98 (1998) 1201-1220.

[11] V.A. Krylova, P.I. Djurovich, B.L. Conley, R. Haiges, M.T. Whited, T.J. Williams, M.E. Thompson, Control of emission colour with N-heterocyclic carbene (NHC) 
ligands in phosphorescent three-coordinate $\mathrm{Cu}(\mathrm{i})$ complexes, Chem. Commun. 50 (2014) 7176-7179. doi:10.1039/C4CC02037E.

[12] H. Naeimi, M. Moradian, Thioether-based copper(I) Schiff base complex as a catalyst for a direct and asymmetric A3-coupling reaction, Tetrahedron: Asymmetry. 25 (2014) 429-434. doi:https://doi.org/10.1016/j.tetasy.2014.02.002.

[13] A. Grirrane, E. Álvarez, H. García, A. Corma, Deactivation of Cationic CuI and AuI Catalysts for A3 Coupling by $\mathrm{CH} 2 \mathrm{Cl} 2$ : Mechanistic Implications of the Formation of Neutral CuI and AuI Chlorides, Angew. Chemie Int. Ed. 53 (2014) 7253-7258. doi:10.1002/anie.201403973.

[14] N. Gommermann, C. Koradin, K. Polborn, P. Knochel, Enantioselective, Copper(I)Catalyzed Three-Component Reaction for the Preparation of Propargylamines, Angew. Chemie Int. Ed. 42 (2003) 5763-5766. doi:10.1002/anie.200352578.

[15] N. Gommermann, P. Knochel, Practical Highly Enantioselective Synthesis of Propargylamines through a Copper-Catalyzed One-Pot Three-Component Condensation Reaction, Chem. - A Eur. J. 12 (2006) 4380-4392. doi:10.1002/chem.200501233.

[16] J.R. Cammarata, R. Rivera, F. Fuentes, Y. Otero, E. Ocando-Mavárez, A. Arce, J.M. Garcia, Single and double A3-coupling (aldehyde-amine-alkyne) reaction catalyzed by an air stable copper(I)-phosphole complex, Tetrahedron Lett. 58 (2017) 40784081. doi:https://doi.org/10.1016/j.tetlet.2017.09.031.

[17] M. Iwamura, S. Takeuchi, T. Tahara, Real-Time Observation of the Photoinduced Structural Change of Bis(2,9-dimethyl1,10-phenanthroline)copper(I) by Femtosecond Fluorescence Spectroscopy: A Realistic Potential Curve of the Jahn-Teller Distortion, J. Am. Chem. Soc. 129 (2007) 52485256. doi:10.1021/ja069300s.

[18] V. Kalsani, M. Schmittel, A. Listorti, G. Accorsi, N. Armaroli, Novel Phenanthroline Ligands and Their Kinetically Locked Copper(I) Complexes with Unexpected 
Photophysical Properties, Inorg. Chem. 45 (2006) 2061-2067.

doi:10.1021/ic051828v.

[19] S.-M. Kuang, D.G. Cuttell, D.R. McMillin, P.E. Fanwick, R.A. Walton, Synthesis and Structural Characterization of $\mathrm{Cu}(\mathrm{I})$ and $\mathrm{Ni}(\mathrm{II})$ Complexes that Contain the Bis[2-(diphenylphosphino)phenyl]ether Ligand. Novel Emission Properties for the Cu(I) Species, Inorg. Chem. 41 (2002) 3313-3322. doi:10.1021/ic0201809.

[20] D. Felder, J.-F. Nierengarten, F. Barigelletti, B. Ventura, N. Armaroli, Highly Luminescent $\mathrm{Cu}(\mathrm{I})$-Phenanthroline Complexes in Rigid Matrix and Temperature Dependence of the Photophysical Properties, J. Am. Chem. Soc. 123 (2001) 6291-6299. doi:10.1021/ja0043439.

[21] M.G. Babashkina, D.A. Safin, Y. Garcia, Heteroleptic $\mathrm{Cu}(\mathrm{I})$ and $\mathrm{Ag}(\mathrm{I})$ complexes of N-thiophosphorylated tris-thioureas and triphenylphosphane, Polyhedron. 33 (2012) 114-118. doi:https://doi.org/10.1016/j.poly.2011.11.028.

[22] D.A. Safin, M.G. Babashkina, M. Bolte, M. Köckerling, Heteroligand copper(I) complexes of $\mathrm{N}$-thiophosphorylated thioureas and phosphanes: Versatile structures and luminescence, Inorganica Chim. Acta. 370 (2011) 59-64. doi:https://doi.org/10.1016/j.ica.2011.01.035.

[23] M.G. Babashkina, D.A. Safin, A. Klein, M. Bolte, Synthesis, Characterisation and Luminescent Properties of Mixed-Ligand Copper(I) Complexes Incorporating NThiophosphorylated Thioureas and Phosphane Ligands, Eur. J. Inorg. Chem. 2010 (2010) 4018-4026. doi:10.1002/ejic.201000165.

[24] C.S. Smith, C.W. Branham, B.J. Marquardt, K.R. Mann, Oxygen Gas Sensing by Luminescence Quenching in Crystals of $\mathrm{Cu}($ xantphos)(phen)+ Complexes, J. Am. Chem. Soc. 132 (2010) 14079-14085. doi:10.1021/ja103112m.

[25] D.A. Safin, C.M.L. Vande Velde, M.G. Babashkina, K. Robeyns, Y. Filinchuk, Mononuclear heteroleptic complexes of copper (I) with 5-phenyl-2, 2'-bipyridine and triphenylphosphine: crystal structures, Hirshfeld surface analysis and luminescence 
properties, New J. Chem. 40 (2016) 6156-6163.

[26] L.-P. Liu, R. Zhang, L. Liu, X.-X. Zhong, F.-B. Li, L. Wang, W.-Y. Wong, G.-H. Li, H.-J. Cong, N.S. Alharbi, A new strategy to synthesize three-coordinate mononuclear copper (I) halide complexes containing a bulky terphenyl bidentate phosphine ligand and their luminescent properties, New J. Chem. 43 (2019) 33903399.

[27] M. Hashimoto, S. Igawa, M. Yashima, I. Kawata, M. Hoshino, M. Osawa, Highly efficient green organic light-emitting diodes containing luminescent three-coordinate copper (I) complexes, J. Am. Chem. Soc. 133 (2011) 10348-10351.

[28] M. Osawa, M. Hoshino, M. Hashimoto, I. Kawata, S. Igawa, M. Yashima, Application of three-coordinate copper(i) complexes with halide ligands in organic light-emitting diodes that exhibit delayed fluorescence, Dalt. Trans. 44 (2015) 83698378. doi:10.1039/C4DT02853H.

[29] Q. Li, L. Liu, X.-X. Zhong, F.-B. Li, A.M. Asiri, K.A. Alamry, N.-Y. Zhu, W.-Y. Wong, H.-M. Qin, Synthesis, Characterization and Luminescent Properties of Copper (I) Halide Complexes Containing 1-(Diphenylphosphino) naphthalene, J. Inorg. Organomet. Polym. Mater. 27 (2017) 101-109.

[30] Y. Tao, K. Yuan, T. Chen, P. Xu, H. Li, R. Chen, C. Zheng, L. Zhang, W. Huang, Thermally Activated Delayed Fluorescence Materials Towards the Breakthrough of Organoelectronics, Adv. Mater. 26 (2014) 7931-7958.

doi:10.1002/adma.201402532.

[31] C. Hay, M. Hissler, C. Fischmeister, J. Rault-Berthelot, L. Toupet, L. Nyulászi, R. Réau, Phosphole-Containing $\pi$-Conjugated Systems: From Model Molecules to Polymer Films on Electrodes, Chem. Eur. J. 7 (2001) 4222-4236.

[32] H.-C. Su, O. Fadhel, C.-J. Yang, T.-Y. Cho, C. Fave, M. Hissler, C.-C. Wu, R. Réau, Toward functional $\pi$-conjugated organophosphorus materials: design of phospholebased oligomers for electroluminescent devices, J. Am. Chem. Soc. 128 (2006) 983995 . 
[33] M. Hissler, C. Lescop, R. Réau, Coordination chemistry of phosphole ligands: From supramolecular assemblies to OLEDs, Comptes Rendus Chim. 11 (2008) 628-640. doi:https://doi.org/10.1016/j.crci.2008.01.010.

[34] G. Mora, B. Deschamps, S. van Zutphen, X.F. Le Goff, L. Ricard, P. Le Floch, Xanthene-Phosphole Ligands: Synthesis, Coordination Chemistry, and Activity in the Palladium-Catalyzed Amine Allylation, Organometallics. 26 (2007) 1846-1855. doi:10.1021/om061172t.

[35] P.-A. Bouit, A. Escande, R. Szücs, D. Szieberth, C. Lescop, L. Nyulászi, M. Hissler, R. Réau, Dibenzophosphapentaphenes: Exploiting P Chemistry for Gap Fine-Tuning and Coordination-Driven Assembly of Planar Polycyclic Aromatic Hydrocarbons, J. Am. Chem. Soc. 134 (2012) 6524-6527. doi:10.1021/ja300171y.

[36] J. Crassous, R. Réau, $\pi$-Conjugated phosphole derivatives: synthesis, optoelectronic functions and coordination chemistry, Dalt. Trans. (2008) 6865-6876.

[37] S. Doherty, E.G. Robins, J.G. Knight, C.R. Newman, B. Rhodes, P.A. Champkin, W. Clegg, Selectivity for the methoxycarbonylation of ethylene versus $\mathrm{CO} \square$ ethylene copolymerization with catalysts based on C4-bridged bidentate phosphines and phospholes, J. Organomet. Chem. 640 (2001) 182-196. doi:https://doi.org/10.1016/S0022-328X(01)01180-9.

[38] J. Hydrio, M. Gouygou, F. Dallemer, J.-C. Daran, G.G.A. Balavoine, New chiral phosphole ligands: their coordination behaviour and application in palladiumcatalysed asymmetric allylic substitution, Tetrahedron: Asymmetry. 13 (2002) 10971102. doi:https://doi.org/10.1016/S0957-4166(02)00256-2.

[39] W.L.F. Armarego, Purification of laboratory chemicals, Butterworth-Heinemann, 2017.

[40] A. Finch, P.J. Gardner, K.K. Sen Gupta, Studies on phenylphosphorus dihalides, J. Chem. Soc. B Phys. Org. (1966) 1162-1164.

[41] P.J. Fagan, W.A. Nugent, Synthesis of main group heterocycles by metallacycle transfer from zirconium, J. Am. Chem. Soc. 110 (1988) 2310-2312. 
[42] P.J. Fagan, W.A. Nugent, J.C. Calabrese, Metallacycle transfer from zirconium to main group elements: a versatile synthesis of heterocycles, J. Am. Chem. Soc. 116 (1994) 1880-1889.

[43] Y. Otero, W. Vera, Y. León, C. Cardozo, D. Peña, A. Arce, Y. De Sanctis, T. Gonzalez, Synthesis, crystal structures and properties of 1, 8-di (quinol-2-yl) octa-1, 7-diyne and 1, 8-di (phenantren-9-yl) octa-1, 7-diyne, J. Chem. Res. 39 (2015) 4852.

[44] S. Alfonso, S. González, A.R. Higuera-Padilla, A. Vidal, M. Fernández, P. Taylor, I. Urdanibia, A. Reiber, Y. Otero, W. Castro, A new complex of copper-phosphole. Synthesis, characterization and evaluation of biological activity, Inorganica Chim. Acta. 453 (2016) 538-546.

[45] C. Hay, C. Fischmeister, M. Hissler, L. Toupet, R. Réau, Electropolymerization of $\pi$ Conjugated Oligomers Containing Phosphole Cores and Terminal Thienyl Moieties: Optical and Electronic Properties, Angew. Chemie Int. Ed. 39 (2000) 1812-1815.

[46] C. Hay, D. Le Vilain, V. Deborde, R. Réau, L. Toupet, 2, 5-Di (2-pyridyl) phospholes: model compounds for the engineering of $\pi$-conjugated donor-acceptor co-oligomers with a chemically tunable HOMO-LUMO gap, Chem. Commun. (1999) 345-346.

[47] A. Tsuboyama, K. Kuge, M. Furugori, S. Okada, M. Hoshino, K. Ueno, Photophysical properties of highly luminescent copper (I) halide complexes chelated with 1, 2-bis (diphenylphosphino) benzene, Inorg. Chem. 46 (2007) 1992-2001.

[48] P.C. Ford, E. Cariati, J. Bourassa, Photoluminescence properties of multinuclear copper (I) compounds, Chem. Rev. 99 (1999) 3625-3648.

[49] J. Nitsch, C. Kleeberg, R. Froehlich, A. Steffen, Luminescent copper (I) halide and pseudohalide phenanthroline complexes revisited: simple structures, complicated excited state behavior, Dalt. Trans. 44 (2015) 6944-6960.

[50] S. Yamaguchi, S. Akiyama, K. Tamao, The coordination number-photophysical properties relationship of trianthrylphosphorus compounds: doubly locked 
fluorescence of anthryl groups, J. Organomet. Chem. 646 (2002) 277-281.

[51] Y. Wang, M.I. Ranasinghe, T. Goodson, Ultrafast fluorescence investigation of excitation energy transfer in different dendritic core branched structures, J. Am. Chem. Soc. 125 (2003) 9562-9563.

[52] R.C. Smith, M.J. Earl, J.D. Protasiewicz, Synthesis and photoluminescent properties of a series of pnictogen-centered chromophores, Inorganica Chim. Acta. 357 (2004) 4139-4143.

[53] Y. Kang, D. Song, H. Schmider, S. Wang, Novel blue phosphorescent group 15 compounds MR3 (M= P, Sb, Bi; R= p-(N-7-azaindolyl) phenyl), Organometallics. 21 (2002) 2413-2421.

[54] C. Fave, T.-Y. Cho, M. Hissler, C.-W. Chen, T.-Y. Luh, C.-C. Wu, R. Réau, First examples of organophosphorus-containing materials for light-emitting diodes, J. Am. Chem. Soc. 125 (2003) 9254-9255. 